EUROPA REGIONUM TOM XXIII ROK 2015

DOI: $10.18276 /$ er.2015.23-25

MIESZKO CIESIELSKI

Instytut Kultury Europejskiej UAM w Gnieźnie

\title{
Doświadczenie krajobrazu jako element różniący turystykę alternatywną i turystykę masową ${ }^{1}$
}

\section{Wprowadzenie}

$\mathrm{T}$

urystyka alternatywna jest zwykle definiowana w opozycji do turystyki masowej. Znawcy problematyki wskazują przy tym na różne kryteria, za pomocą których przeprowadzane jest rozróżnienie między tymi typami. W niniejszym eseju również podjęte zostanie zagadnienie różnicy pomiędzy turystyką alternatywną a masową. Rozróżnienie to będzie przeprowadzone ze względu na dwa rodzaje doświadczania krajobrazu. Wydaje się bowiem, że idea turystyki alternatywnej zakłada swoiste „procesualne” i ,uczestniczące” pojęcie krajobrazu, który rozumiany jest jako dynamiczna przestrzeń życia, a nie jako malowniczy widok rozpościerający się przed oczami zdystansowanego turysty. A zatem, celem stawianym w niniejszym artykule jest przybliżenie dwóch ujęć doświadczenia krajobrazu i wykazanie, że można je zaliczyć do cech różnicujących turystykę alternatywną i masową.

\section{Turystyka alternatywna - zasadnicze rysy}

Turystyka alternatywna jest stosunkowo nowym przejawem, charakteryzowanym na tle turystyki masowej, którą w tym kontekście można by też określić jako tradycyjną ${ }^{2}$. Różne czynniki wpłynęły na ukształtowanie się nowego modelu

\footnotetext{
${ }^{1}$ Tekst napisany w ramach projektu Krajobraz kulturowy; projekt został sfinansowany ze środków Narodowego Centrum Nauki przyznanych na podstawie decyzji numer DEC2011/01/B/HS1/01728.

${ }^{2}$ Na temat turystyki masowej zob. m.in.: J. Urry, Spojrzenie turysty, Wydawnictwo. Naukowe PWN, Warszawa 2007.
} 
organizacji przedsięwzięć turystycznych. Ważnym elementem, niejako źródłem ideowym turystyki alternatywnej, jest sprzeciw wobec konsumpcyjnego modelu życia, który odbija swe piętno również w dziedzinie aktywności turystycznej.

„Nowi turyści - pisze A. Niezgoda - chcą omijać zatłoczone centra turystyczne, poszukują kontaktu z miejscową ludnością, przeciwstawiają się izolacji turystów w specjalnych enklawach. Często motywy ich podróżowania związane są z krajoznawstwem i edukacją"”.

Definicji turystyki alternatywnej jest bardzo wiele - różni badacze bowiem, przyjmując odmienną perspektywę analizy, podkreślają takie, a nie inne aspekty związane z turystyka, co wpływa na jej rozumienie. Jak pisze A. Niezgoda:

„Współczesne pojęcie «turystyka alternatywna» wprowadza pewien zamęt do terminologii przedmiotu. Niektórzy uważają, że jest to każda forma turystyki «małej skali» w przeciwieństwie do turystyki masowej”"

Dodatkowe utrudnienie w dokładnym określeniu, czym ma być turystyka alternatywna, stanowi wielość czasami bliskoznacznych pojęć określających formy turystyki mniej lub bardziej przeciwstawianych turystyce masowej (,tradycyjnej”); są to m.in.: turystyka „łagodna”, „,odpowiedzialna”, „przyjazna środowisku”, ,zrównoważona",.

Jedną ze strategii przyjmowanych przy definiowaniu turystyki alternatywnej jest wskazywanie jej istotnych cech i zestawianie ich z cechami turystyki masowej. Na podstawie rozważań D.B. Weavera ${ }^{6}$ i A. Kowalczyka ${ }^{7}$ można uwypuklić różnice w obrębie trzech następujących kryteriów: rynku, atrakcji i bazy noclegowej ${ }^{8}$.

Otóż, jeśli chodzi o rynek, to turystyka alternatywna charakteryzuje się indywidualną organizacją podróży i brakiem wyraźnej sezonowości. Ponadto, trudno także wskazać na silnie dominujące miejsca, jako cel podróży turystycznych. Przeciwnie ma się rzecz w przypadku turystyki masowej. Tu mamy do czynienia $\mathrm{z}$ du-

${ }^{3}$ A. Niezgoda, Obszar recepcji turystycznej $w$ warunkach rozwoju zrównoważonego, Wydawnictwo A E w Poznaniu, Poznań 2006, s. 33.

${ }^{4}$ A. Niezgoda, Rola różnych koncepcji i form rozwoju turystyki w dażeniu do celów rozwoju zrównoważonego, „Turyzm”, 2008, nr 18/2, s. 81.

${ }^{5}$ Tamże, s. 80-85. Por. też w: Turystyka zrównoważona, red. A. Kowalczyk, Wydawnictwo Naukowe PWN, Warszawa 2010, s. 25-31.

${ }^{6}$ D.B. Weaver, Ecoturismin the context of Other tourism types, w: The Encyclopedia of ecotourism, red. D.B. Weaver, CABI Publishing, Oxon - New York 2001, s. 73-83.

${ }^{7}$ Turystyka zrównoważona..., s. 29.

${ }^{8}$ Charakteryzując turystykę alternatywną i masową będziemy je rozumieć jako typy idealne w sensie weberowskim, czyli jako konstrukty myślowe przedstawiające zespół cech, które pozwalają jednoznacznie zdefiniować poszczególne pojęcie turystki, a które w rzeczywistości empirycznej z taką wyrazistością nie występują. 
żymi pakietami turystycznymi, adresowanymi do masowego odbiorcy, sezonowością organizacji przedsięwzięć turystycznych oraz kilkoma dominującymi rynkami turystycznymi, preferowanymi przez większą część masowego odbiorcy.

Charakter atrakcji turystycznych jest również odmienny w obydwu typach turystyki. Normą turystyki alternatywnej jest niski stopień komercjalizacji i unikanie spreparowanych specjalnie dla turystów miejsc i wydarzeń wypełniających czas wycieczki, które moga jawić się jako „standardowe” i „przewidywalne”. Dąży się natomiast do zachowania ,autentycznego” kontaktu zarówno z przyrodą jak i tubylczą ludnością, której zwyczajne, codzienne życie staje się jedną $\mathrm{z}$ atrakcji turystycznych. Zupełnie inaczej wygląda to w przypadku turystyki masowej, nastawionej na wysoki stopień komercjalizacji i duży poziom nagromadzenia różnego typu atrakcji, które czynią określone miejsce wyrwanym z przestrzeni zwyczajnego życia.

Turystyka alternatywna różni się od masowej także rodzajem bazy noclegowej. Jest ona w swoisty sposób rozproszona przestrzennie, a jej ograniczony rozmiar (niskie zagęszczenie) nie powoduje zjawiska „naprzykrzania się”. Stylem architektonicznym infrastruktura noclegowa nie odbiega od miejscowej, rodzimej (,nieturystycznej”) zabudowy, co powoduje swoiste wkomponowanie się bazy noclegowej w przestrzeń danego miejsca. Odwrotnie jeśli chodzi o turystykę masową wymagającą dużego zaplecza noclegowego, które jest w wysokim stopniu przestrzennie skoncentrowane i zestandaryzowane, co sprawia, że jest ono „obce” i nie pasujące do lokalnego otoczenia.

Oprócz powyższych kryteriów, badacze wskazują także na charakterystyczną postawę turysty, która polega na próbie pokonania dystansu, jaki rodzi się pomiędzy „oglądającym turystą” a „oglądanym miejscem i ludnością”. Turyści poszukuja „głębokiego” kontaktu z otoczeniem, który jest związany z ,autentycznym zainteresowaniem dziedzictwem kulturowym (zabytkami, folklorem, miejscami związanymi z ważnymi wydarzeniami itp.) oraz z ich uczestnictwem w szeroko rozumianym współczesnym życiu kulturalnym"9.

I - dodajmy - ów ,głęboki” kontakt może mieć miejsce nie tylko w odniesieniu do atrakcji kulturowych, obejmując uczestnictwo w praktykach społecznych i empatyczną więź ze społecznością lokalną, lecz także do przyrody, kiedy to natura zaczyna być postrzegana nie przez pryzmat malowniczego widoku, w którym zaangażowany jest tylko wzrok, ale jest odczuwana za pośrednictwem

9 A. Kowalczyk, Wspótczesna turystyka kulturowa - między tradycja a nowoczesnościq, w: Turystyka kulturowa. Spojrzenie geograficzne, red. A. Kowalczyk, WGiSR, Warszawa 2008, s. 13. 
również innych zmysłów, które łącznie umożliwiają odkryć i niejako „poczuć” różne wymiary przyrody.

Warto zatem wskazać dodatkowe kryterium różnicujące turystykę alternatywną od masowej, które nie jest związane z wielkością natężenia ruchu turystycznego, typem odwiedzanego miejsca, czy charakterystyką bazy noclegowej, zwłaszcza, że - jak podkreślają niektórzy badacze - w ostatnim czasie różnice w tych aspektach ulegają zatarciu. Wskazane niżej kryterium związane jest z dwojakim możliwym doświadczeniem krajobrazu: jako malowniczy widok bądź jako dynamiczna przestrzeń życia.

\section{Dwa ujęcia krajobrazu: jako „idea” i jako „proces”}

Krajobraz w perspektywie namysłu estetycznego może być rozumiany dwojako. B. Frydryczak mówi w tym kontekście o dwóch optykach, sensach krajobrazu wyznaczonych dwiema kategoriami estetycznymi: malowniczości (the picturesque) i wzniosłości.

„Linia demarkacyjna, przebiegająca między the picturesque a wzniosłością, stawia na przeciwległych biegunach ideę bezczasowości i ahistoryczności pięknej natury i historyczny, procesualny wymiar piękna, kontemplację i polisensoryczne doświadczenie, to co stałe i to co zmienne" ${ }^{10}$.

Doświadczenie estetyczne krajobrazu może zatem przebiegać, z jednej strony, w postawie kontemplacyjnej, która ujawnia krajobraz jako „ideę” z charakterystyczną optyką zawierającą:

- bezczasowość, ahistoryczność,

- stałość,

- malowniczość,

- obrazowość,

- wizualność ${ }^{11}$.

\footnotetext{
${ }^{10}$ B. Frydryczak, Krajobraz. Od estetyki the picturesque do doświadczenia topograficznego, Wydawnictwo PTPN, Poznań 2013, s. 49.

11 Początki takiego pojmowania krajobrazu w praktykach podróżniczych zbieżne są z XVIII-wiecznym rozkwitem malarstwa pejzażowego; jak stwierdza A. Wieczorkiewicz: „w końcu XVIII wieku wzorce elitarnych podroży zaczęły ulegać zmianom (...). Natura zaczęła się wówczas jawić w nowym świetle. Podróżnych zachęcano do kontemplowania pięknych pejzaży. Patrzyli więc na nie jakby były obrazami, a opisywali tak, by wydobyć walor malowniczości”, A. Wieczorkiewicz, Apetyt turysty. O doświadczaniu świata $w$ podróży, TAiWPN Universitas, Kraków 2008, s. 103.
} 
Z drugiej zaś strony, doświadczenie estetyczne może być inicjowane postawą uczestnicząca, przyjmującą optykę ,procesu”, dla której charakterystyczne są:

- czasowość i historyczność,

- procesualność,

- postrzeganie interakcji świata kultury i natury,

- polisensoryczność ${ }^{12}$.

Obydwa sensy doświadczenia krajobrazu wyrazić można również przy pomocy kategorii działania. Można bowiem wyróżnić „bycie wobec” krajobrazu, które zakłada działanie bierne, nastawione wyłącznie na swoiste pozyskiwanie wrażeń wizualnych ${ }^{13}$. Podmiot takiego działania staje się neutralny, jest wyłącznie „pojemnikiem”, do którego wrzucane są kolejne obrazki, będące wynikiem kontaktu z otoczeniem. Inaczej rzecz wygląda w przypadku „bycia w” krajobrazie, które jest działaniem aktywnym, niejako uczestniczącym w procesie tworzenia krajobrazu jako miejsca dynamicznych żywiołów i życia ludzkiego, które się z nimi zmaga, ale też z którymi harmonijnie koegzystuje.

„Pojęcie krajobrazu (...) mieszczące się w formule procesualnego rozumienia krajobrazu, wywołuje typ doświadczenia, które nie sposób wiązać ze spojrzeniem panoramicznym. (...) Spojrzenie panoramiczne dawało poczucie «brania krajobrazu w posiadanie», krajobraz uczestniczący, przez bezmiar oferowanych wrażeń, obejmuje nas «w swoje posiadanie» ${ }^{14}$.

„Bycie w” krajobrazie zakłada ideę podmiotu twórczego, który jest nie tylko zbieraczem gotowych obrazków-widoków, lecz który niejako współtworzy krajobraz dzięki żywej interakcji z otoczeniem. To, jakie interakcje pomiędzy podmiotem a doświadczanym otoczeniem mają miejsce, jak głęboka i pełna jest relacja między nimi, wpływa w sposób istotny na „obraz” postrzeganego otoczenia.

${ }^{12}$ Źródeł takiego rozumienia krajobrazu badacze upatrują w romantyzmie; B. Frydryczak pisze w ten sposób: „Romantyczna «inność» natury bierze się z odmiennej sytuacji człowieka (...). Zmieniają się relacje człowieka z przyrodą (...), dotychczasowa linia demarkacyjna osadzona jak barierka w punkcie widokowym, zniknęła. (...) Kluczowa jest to rola podmiotu, najpierw obserwatora, który stopniowo przeobraża się w «partnera» natury i uczestnika krajobrazu”, B. Frydryczak, Krajobraz. Od estetyki the picturesque do doświadczenia topograficznego..., s. 176.

${ }^{13}$ B. Frydryczak, Krajobraz. Od estetyki the picturesque do doświadczenia topograficznego..., s. 50. A. Berleant omawiając analogiczne rozróżnienie posługuje się pojęciami krajobrazu panoramicznego i krajobrazu uczestniczącego; zob. w: A. Berleant, Art and Engagement, Temple University Press, Philadelphia 1991, s. 62 i n.

${ }^{14}$ B. Frydryczak, Krajobraz. Od estetyki the picturesque do doświadczenia topograficznego..., s. 228. 


\section{3. „Przestrzeń życia” - doświadczenie krajobrazu specyficzne dla turystyki alternatywnej}

Dwa zarysowane wyżej rodzaje doświadczenia krajobrazu można wykorzystać jako dodatkowe kryterium rozróżnienia turystki alternatywnej i masowej. Dla turysty masowego, doświadczającego widoków krajobrazowych typowa jest postawa zdystansowanego widza. Atrakcje polegające na poznawaniu pięknych widoków zwykle mają miejsce ze specjalnie do tego celu przygotowanych tarasów, z których turysta może obejrzeć panoramę okolicy. Choć może to być porywające doświadczenie krajobrazu, to jednakże nie pozwala ono przezwyciężyć dystansu, jaki nieuchronnie rodzi się między oglądającymi (często gromadnie) a przestrzenią oglądaną ${ }^{15}$.

W ramach turystyki alternatywnej próbuje się odejść od zestandaryzowanych sposobów organizacji przedsięwzięć turystycznych z ich masowym charakterem, na rzecz zindywidualizowanych ofert zorientowanych na pogłębioną interakcję turysty z miejscem odwiedzanym. Dla tego typu turyzmu charakterystyczne wydaje się pojmowanie krajobrazu jako „przestrzeni życia”, miejsca zmiennego, kształtowanego przez człowieka i jednocześnie człowieka kształtującego. Postawa polegająca na „byciu w” krajobrazie jest znamienna dla turysty alternatywnego.

Powyższe spróbujemy uzasadnić (w jakiejś mierze przynajmniej) na przykładzie dwóch odmian turystyki alternatywnej: winiarskiej i poprzemysłowej. Wybór ten podyktowany jest odmiennym charakterem miejsc zwiedzanych. W pierwszym przypadku mamy do czynienia ze specyficznym krajobrazem rolniczym, który choć zaliczany do krajobrazu kulturowego, wiele elementów konstytutywnych zawdzięcza przyrodzie. W drugim przypadku zaś, krajobraz jest w przeważającej mierze ukształtowany wyłącznie przez pozostałości ludzkiej działalności. Pomimo tej różnicy, zarówno krajobraz winiarski, jak i poprzemysłowy w pełni może być „odkryty” i doświadczony przez postawę szukającą w krajobrazie nie malowniczego widoku, lecz przestrzeni życia.

${ }^{15}$ Takie doświadczenie krajobrazu charakterystyczne jest m.in. w ramach tzw. wycieczek objazdowych, gdzie niejednokrotnie widok krajobrazowy ujmowany jest z jadącego autokaru; na ten temat pisze m.in. M. Kostaszuk-Romanowska, Rola krajobrazu we współczesnych praktykach turystycznych, w: Krajobraz kulturowy, red. B. Frydryczak, M. Ciesielski, Wydawnictwo PTPN, Poznań 2014, s. 239-250. 
Jedną z odmian turystyki alternatywnej jest enoturystyka ${ }^{16}$, organizowana w regionach uprawy winorośli i produkcji wina, gdzie obok atrakcji związanych z konsumpcją szlachetnych trunków i poznawaniem ich wytwarzania, ważnym jej walorem jest „krajobraz winiarski”:

„Z uprawą winorośli jest związany pewien charakterystyczny typ krajobrazu kulturowego, na który składają się nie tylko winnice, ale również określony typ zabudowy wiejskiej, rozplanowanie budynków itp."17

Krajobraz enologiczny rozumiany jest jako rodzaj krajobrazu rolniczego, w którym zasadniczą rolę odgrywa nie rozpościerający się widok upraw, lecz swoista całość złożona - jak określa to D.J. Telfer ${ }^{18}$, autor terminu „winescape” $-\mathrm{z}$ trzech elementów:

- winnic,

- działań związanych z uprawą, zbieraniem winorośli i przetwarzaniem winogron,

- miejscami produkcji i przechowywania wina.

Krajobraz winiarski jest raczej przestrzenią specyficznego życia wiejskiego, w którym element ludzkiego praxis związany z uprawą, a następnie produkcją win, wydaje się być najważniejszy. W krajobrazie regionów winiarskich najbardziej interesujący wydaje się być zawarty w nim ów proces swoistej współpracy człowieka z naturą we wspólnym dążeniu do jednego celu: wytworzenia najszlachetniejszego z trunków. Już samo doświadczenie takiego krajobrazu w jakiejś mierze zdradza turyście kształt i specyfikę życia lokalnej społeczności. Aby jednakże było możliwe takie doświadczenie, turysta musi przyjąć odpowiednią postawę. Musi przezwyciężyć dystans, który oddziela go od otoczenia; musi przestać być oglądającym turystą, a stać się zanurzonym w społeczności tubylczej smakoszem wina. Więcej jeszcze: powinien stać się wytwór-

16 „Niezwykła popularność turystyki winiarskiej pozwala na wyodrębnienie jej jako osobnej formy turystyki kulturowej. Turystyka winiarska, czyli enoturystyka (z greckiego oinos - wino) nawiązuje do tak ważnego elementu życia człowieka, jakim jest przygotowanie i delektowanie się napojem szczególnym, jakim jest wino. Ta forma turystyki staje się obecnie modną i jest najszybciej rozwijającą się gałęzią światowego przemysłu turystycznego" - Z. Kruczek, Enoturystyka w Polsce i na świecie, s.1; http://www.proksenia.pl/download/enoturystyka_wspolczesne_formy_ turystyki kulturowej.pdf (29.10.2014).

${ }_{17}$ Turystyka zrównoważona..., s. 212.

${ }^{18}$ D.J. Telfer, The Northeast wine route: wine tourism In Ontario, Canada and New York State, w: Wine tourism around the world: development, management and markets, red. C.M. Hall, L. Sharples, B. Cambourne, N. Macionis, Butterworth-Heinemann, Oxford-Amsterdam-BostonLondon-New York-Paris-San Diego-San Francisco-Singapore-Sydney-Tokyo 2002, s. 254, podaję za: Turystyka zrównoważona..., s. 213. 
cą wina - zebrać grona, uczestniczyć w wytwarzaniu soku, butelkować itd. Zupełnie inaczej doświadczany i rozumiany jest krajobraz regionów winiarskich przez turystę tylko oglądającego piękne malownicze widoki, co jest charakterystyczne dla turystyki masowej, w porównaniu z turystą, który choć przez krótką chwilę całkowicie pozwolił, aby pochłonęła go praktyka życiowa ludzi i specyfika oglądanych miejsc, co wydaje się być istotnym wyznacznikiem turystyki alternatywnej.

Turystyka poprzemysłowa to inna odmiana turystyki alternatywnej i można ją ogólnie zdefiniować jako taką formę turyzmu, która ,zainteresowana jest produkcją przemysłowa, jej procesami, otoczeniem i efektami"19.

Turystyka poprzemysłowa rozwija się często na terenach gospodarczo już nieaktywnych zgodnie $\mathrm{z}$ pierwotnym swym przeznaczeniem. Pozostałości w postaci budynków fabryk, całych kompleksów architektury przemysłowej, pomniejszych urządzeń i maszyn stanowią podstawową atrakcję turystyczną. Krajobraz poprzemysłowy dopełnia zestaw walorów takich miejsc.

Przywoływanie w pamięci minionych czasów - jak pisze J. Urry - ,jest być może dominującą «praktyką» - spektaklem z udziałem ,prawdziwych aktorów, którzy rozbudzają wspomnienia; i zwiedzających, którzy często współpracują, żeby wspomnienia wywołać" 20 .

Celem turystyki poprzemysłowej nie jest tylko odwiedzenie i poznanie miejsc związanych z ośrodkami przemysłowo-produkcyjnymi minionych czasów. Ważniejsze wydaje się przeżycie polegające na przypomnieniu sobie „dawnego życia", kształtowanego sposobem produkcji, używanymi narzędziami oraz szeroko rozumianym otoczeniem - specyficznym krajobrazem, spajającym w całość poszczególne przejawy aktywności życiowej ${ }^{21}$. Jedną z ważniejszych atrakcji turystyki poprzemysłowej nie jest poznanie materialnych pozostałości technicznych, lecz dotarcie do wymiaru ludzkiego praxis, w swoisty sposób zachowanego i ukrytego w tychże pozostałościach.

\footnotetext{
${ }^{19}$ T. Jędrysiak, Turystyka kulturowa w obiektach poprzemystowych - zagadnienia ogólne, ,Turystyka Kulturowa” 2011, nr 6, s. 18. Por. M. Derek, Turystyka przemystowa jako forma turystyki zrównoważonej, w: Uwarunkowania i plany rozwoju turystyki. Turystyka zrównoważona, red. Z. Młynarczyk, I. Potocka, A. Zajadacz, Bogucki Wydawnictwo Naukowe, Poznań 2010, s. 33 i n.

${ }^{20}$ J. Urry, Spojrzenie turysty ..., s. 166.

${ }^{21}$ Przeżyciowo-przypomnieniowy wymiar turystyki poprzemysłowej jest podkreślany przez różnych badaczy; zob. m.in. w: A. Mikos v. Rohrscheidt, Turystyka kulturowa. Fenomen, potencjat, perspektywy, GWSH Milenium, Gniezno 2008.
} 
Taki wymiar spotkania ze zwiedzanym miejscem, odkrywającym praktykę człowieka, a nie tylko jej wytwór, jest możliwy z perspektywy „,zaangażowanego widza", który nie poprzestaje na wzrokowym oglądzie i sfotografowaniu historycznej infrastruktury przemysłowej, lecz ponadto będzie miał możliwość praktycznego i ,wielozmysłowego" kontaktu z budynkami i urządzeniami. Dla osiągnięcia takiego efektu niezbędne jest uruchomienie wybranych maszyn, możliwość praktycznej nimi manipulacji, przejście poprzez kolejne budynki fabryki zgodnie z procesem produkcyjnym, zapach wykorzystywanych substancji, odgłosy urządzeń itp. Taka forma uczestnictwa w miejscu historyczno-przemysłowym zakłada u swych podstaw aktywne „bycie w” krajobrazie, w tym przypadku krajobrazie poprzemysłowym, a nie „bycie wobec” krajobrazu.

\section{Podsumowanie}

Rozwijająca się coraz szybciej - i to w wielu swych odmianach - turystyka alternatywna wymaga specyficznego nastawienia turysty wobec miejsc zwiedzanych. Rozróżnienie przez teoretyków dwóch ujęć doświadczenia krajobrazu: zdystansowanego i wizualnego „bycia wobec” krajobrazu oraz zaangażowanego i wielozmysłowego „bycia w” krajobrazie, może się przysłużyć do pełniejszej charakterystyki turystyki alternatywnej w odróżnieniu od turystyki masowej.

Analiza dwóch odmiany turystyki alternatywnej: winiarskiej i poprzemysłowej, pozwala - w jakiejś mierze przynajmniej - uzasadnić tezę że dla tego typu turystyki charakterystyczne jest rozumienie krajobrazu jako „przestrzeni życia”, miejsca zmiennego, kształtowanego przez człowieka i jednocześnie człowieka kształtującego. Postawa polegająca na „byciu w” krajobrazie jest charakterystyczna dla turystyki alternatywnej - zindywidualizowanej, szanującej lokalne miejsca i ludzi oraz zmierzającej do głębszego, dynamicznego i autentycznego kontaktu czy wręcz utożsamienia się z miejscami odwiedzanymi.

\section{Bibliografia}

Berleant A., Art and Engagement, Temple University Press, Philadelphia 1991.

Derek M., Turystyka przemystowa jako forma turystyki zrównoważonej, w: Uwarunkowania i plany rozwoju turystyki. Turystyka zrównoważona, red. Z. Młynarczyk, I. Potocka, A. Zajadacz, Bogucki Wydawnictwo Naukowe, Poznań 2010.

Frydryczak B., Krajobraz. Od estetyki the picturesque do doświadczenia topograficznego, Wydawnictwo PTPN, Poznań 2013. 
Jędrysiak T., Turystyka kulturowa w obiektach poprzemyslowych - zagadnienia ogólne, „Turystyka Kulturowa” 2011, nr 6.

Kostaszuk-Romanowska M., Rola krajobrazu we wspótczesnych praktykach turystycznych, w: Krajobraz kulturowy, red. B. Frydryczak, M. Ciesielski, PTPN, Poznań 2014.

Kowalczyk A., Wspótczesna turystyka kulturowa - między tradycja a nowoczesnościa, w: Turystyka kulturowa. Spojrzenie geograficzne, red. A. Kowalczyk, WGiSR, Warszawa 2008.

Kruczek Z., Enoturystyka w Polsce i na świecie, http://www.proksenia.pl /download/enoturysty kawspolczesne_formy_turystyki_kulturowej.pdf, s. 1-10; (29.10.2014).

Niezgoda A., Obszar recepcji turystycznej w warunkach rozwoju zrównoważonego, Wydawnictwo AE w Poznaniu, Poznań 2006.

Niezgoda A., Rola różnych koncepcji i form rozwoju turystyki w dqżeniu do celów rozwoju zrównoważonego, „Turyzm” 2008, nr 18/2.

Rohrscheidt A. Mikos von, Turystyka kulturowa. Fenomen, potencjat, perspektywy, GWSH Milenium, Gniezno 2008.

Telfer D.J., The Northeast wine route: wine tourism In Ontario, Canada and New York State, w: Wine tourism around the world: development, management and markets, red. C.M. Hall, L. Sharples, B. Cambourne, N. Macionis, Butterworth-Heinemann, Oxford-Amsterdam-Boston-London-New York-Paris-San Diego-San FranciscoSingapore-Sydney-Tokyo 2002.

Turystyka zrównoważona, red. A. Kowalczyk, Wydawnictwo Naukowe PWN, Warszawa 2010. Urry J., Spojrzenie turysty, Wydawnictwo Naukowe PWN, Warszawa 2007.

Weaver D.B., Ecoturismin the context of Other tourism types, w: The Encyclopedia of ecotourism, red. D.B. Weaver, CABI Publishing, Oxon-New York 2001.

Wieczorkiewicz A., Apetyt turysty. $O$ doświadczaniu świata $w$ podróży, TAiWPN Universitas, Kraków 2008.

\section{A landscape as the element distinguishing alternative and mass tourism Summary}

The article addresses the issue of difference between alternative tourism and mass tourism. In various studies, the elements quoted most frequently in this context include specificity of the market (e.g. individual customers, lack of clear-cut seasons) types of attractions (e.g. genuine locations and events which have not been previously constructed, prepared or arranged, low concentration of attractions) and type of accommodation (dispersed accommodation facilities, native architectural styles). In turn, the author suggests two notions of experiencing landscape (distanced "being with respect to" landscape, i.e. outside of it, and participating "being in" the landscape) and employs them to draw a distinction between alternative and mass tourism. The concept of alternative tourism presupposes the latter understanding of experience, meaning a particular "processual" and "participant" notion of landscape. It is the landscape construed as a dynamic domain of life, not a picturesque view extending before the eyes of a distanced tourist, that constitutes a characteristic of alternative tourism. 